\title{
Some Economic Considerations in the U.S. War on Terrorism
}

\author{
By David Gold*
}

\section{"Suicide bombing is a corporate effort."}

Certainly since September 11, 2001, if not earlier, the "war" against international terrorism has become the central organizing principle of United States foreign and military policy. Like most wars, the war against international terrorism is largely defined in terms of military and political objectives, yet other considerations are also of importance. Terrorism is a complex phenomenon that is difficult to pin down. As the terrorism expert Jessica Stern has reminded us, "The student of terrorism is confronted with hundreds of definitions in the literature."2 Many analyses of terrorism, along with the prescriptions for dealing with it, emphasize its political, social, ideological, and economic aspects, although these factors are usually given less emphasis than security factors in policy formation.

Popular discussions of the economic aspects of terrorism tend to focus on how to cut off the flow of financial resources to terrorist organizations, how to allocate budgetary resources to fighting terrorism, and whether economic deprivation fosters international terrorism. Yet the economic aspects of terrorism are far more complex. There are economic costs that are the direct result of terrorist activities, and there are a variety of costs beyond those delineated by government budgets crafted to fund a war against terrorism. The sizeable nature of these costs suggests that enhanced efforts to weaken the sources of terrorism could create substantial economic benefits.

The linkage between terrorism and poverty is too simple, and often incorrect. Instead, the links have to do with the structure of rewards and systems of incentives that evolve in many societies. And the role of economics in fighting terrorism can involve far more than trying to disrupt financial networks. Terrorism, and the measures taken to counter terrorism, both carry economic costs. Yet terrorism does have economic sources, and the attempt to offset, and even defeat, terrorism would benefit from the adoption of economic strategies.

This paper will discuss four aspects of the economics of terrorism, delineating the costs of terrorism, evaluating the costs of fighting terrorism, assessing the sources of terrorism, and presenting some alternatives in the fight against terrorism.

\footnotetext{
* David Gold is Professor of Economics in the Graduate Program in International Affairs at New School University in New York.

1 "Special Report: Suicide Terrorism: Martyrdom and Murder," The Economist, January 10, 2004.

${ }^{2}$ Jessica Stern, Terror In the Name of God: Why Religious Militants Kill (New York:

HarperCollins, 2003), xx.
} 


\section{Economic Costs of Terrorism}

The immediate economic costs of terrorism are fairly obvious: destruction of life and property. In the case of the September 11 attacks, while the personal costs borne by those touched by the tragedy are immense and can linger for substantial periods of time, and while the magnitude of loss measured in dollars appears huge - \$33 to \$36 billion in New York City, according to one authoritative estimate - the destruction of physical and human capital and related loss of output was quite small in relation to the size of the economy. Although business activity, and especially air travel, suffered setbacks, the regional and national economies appear to have recovered and are now dominated by the trends and cyclical patterns in place prior to September $2001 .^{3}$

When terrorism persists for long periods of time, the costs can continue to mount. Countries or regions that depend heavily on tourism have been found to suffer significant economic losses from the persistence of terrorism. A study of the Basque region in Spain found a decline in per capita GDP of ten percentage points relative to a control as a result of a decline in tourism induced by a wave of terrorist violence by the separatist group ETA. ${ }^{4}$ Declines in tourism-related spending and foreign exchange earnings as a result of terrorism have also been identified for Austria, Egypt, Greece, Israel, Italy, Kenya, and Turkey. ${ }^{5}$ Terrorism also appears to reduce inflows of foreign direct investment. ${ }^{6}$ With the threat of terrorism, normal business dealings and consumption activities require more time, extra security and, because they entail greater risk, often require higher compensation. Thus, terrorism can lead to a general slowdown in economic activity. The Bank of Israel estimated that the country's 2002 GDP was down by between 3 and 3.8 percent as a result of the second Palestinian Intifada, which began toward the end of 2000. The initial negative impacts on tourism, exports to the occupied territories, and construction were magnified as individuals began to translate the persistence of terrorist incidents into perceptions of a long-term decline in their income, and as a result reduced their con-

\footnotetext{
${ }^{3}$ Jason Bram, James Orr, and Carol Rapaport, "Measuring the Effects of the September 11 Attack on New York City," and Jason Bram, Andrew Haughwout, and James Orr, "Has September 11 Affected New York City's Growth Potential?" Federal Reserve Bank of New York Economic Policy Review 8:2 (November 2002), www.nyfed.org/research/epr/2002.html. For additional estimates of the costs of the 9/11 attacks, see Robert Kelleher, "The Economic Costs of Terrorism," Joint Economic Committee, United States Congress, May 2002.

${ }^{4}$ Alberto Abadie and Javier Gardeazabal, "The Economic Costs of Conflict: A Case-Control Study for the Basque Country," National Bureau of Economic Research Working Paper No. W8478, September 2001, www.nber.org/papers/W8478.

${ }_{5}^{5}$ Todd Sandler and Walter Enders, "An Economic Perspective on Transnational Terrorism," European Journal of Political Economy, (forthcoming), www-ref.usc.edu/ tsandler/complete-terror02.pdf; Arthur Andersen, Inc., "Tourism and Terrorism - The Road to Recovery in Egypt," December 2000, www.hotel-online.com?Trends/Andersen/2001_Egypt.html; William Wallis, “Terror Takes Toll on Kenya's Tourism Industry," Financial Times, December 8, 2003.

${ }^{6}$ Walter Enders and Todd Sandler, "Terrorism and Foreign Direct Investment in Spain and Greece," Kyklos 49:3 (1996): 331-52.
} 
sumption. Thus, a wider range of economic activities became affected. ${ }^{7}$

\section{Economic Costs of Fighting Terrorism}

Fighting terrorism requires resources, so there is an immediate economic cost that terrorism imposes. Businesses are forced to allocate more resources to security as the threat of terrorism increases. Terrorists use violence for dramatic effect, and acts of terrorism appear to the victims to be random. Thus, societies see terrorism as an insurance problem, the rough equivalent of an "act of god." As such, there are additional costs to develop and institute appropriate insurance products. In addition, time lost due to tighter restrictions on travel, extra effort to get goods through customs, and greater difficulties for workers moving across borders are all costs borne by both business and consumers.

These extra costs are similar to a tax levied on economic activities. They require resources that can as a result not be used elsewhere. Those who supply some of the services now in demand, such as security firms, may see their activities increase, but this is at the expense of other activities that are likely to be more productive. The contribution of security spending is most clearly linked to the problems it is designed to solve: crime, terrorism, war, etc. Resolving or reducing the negative impacts of a security problem can restore a status quo ante, but it does not provide a continuing benefit over time.

The most visible forms of anti-terrorist expenditures are those undertaken by governments. In the United States, the homeland security function in the federal government budget has been added since September 11. While most of the activities contained within the new function were already being carried out prior to the terrorist attacks, new ones have been added, and the older ones have been given new urgency. The new Department of Homeland Security saw its budget jump from $\$ 17.5$ billion in Fiscal Year (FY) 2002 to $\$ 31$ billion in FY2003. Of course, spending by the Defense Department, the Justice Department, the Treasury Department, and other government agencies, including the Central Intelligence Agency (whose budget is never made public), has also jumped as a result of activities undertaken in the war against terrorism.

Government spending, of course, has a demand-stimulating impact, especially when financed by deficits. Offsetting this effect is the fact that security-related outlays tend to have substantial external leakages, as illustrated by the continuing spending for the occupations and military activities in Afghanistan and Iraq. All outlays have opportunity costs, in that more spending in one area implies less spending in another. In the aggregate, increased U.S. spending on national defense and homeland security, combined with the Bush Administration's tax cutting agenda, has reduced natural spending increases in areas that are potential contributors to economic growth and national security.

\footnotetext{
${ }^{7}$ Bank of Israel, "The Economy: Development and Policies," Bank of Israel Annual Report - 2002, July 2003, www.bankisrael.gov.il/deptdata/mehkar/doch02/eng/dochoze.htm\#topart1
} 
For example, a number of federal government civilian programs in health care and education, which are important components of human capital formation, have already had their funding growth curtailed and are slated for funding cuts in the future. ${ }^{8}$ Moreover, there is a trickle-down effect from the administration's tax cuts. State governments use essentially the same base for income and wealth tax purposes as the federal government, leading to revenue shortfalls at the state level as the federal government cuts its tax rates. With states unable to run deficits, they are forced to cut spending. Heavy losers have been health care, education, and public safety, such as police, fire, and emergency services - the much-praised "first responders" who performed so well on September 11. ${ }^{9}$ The combination of spending growth and tax rate cuts have led to high federal budget deficits, which have increased the likelihood of significant upward movements in interest rates. In the view of some knowledgeable observers, these developments could impose costs on the economy in the future in terms of foregone growth opportunities, especially in the context of the need to allocate greater resources to an aging population. ${ }^{10}$

It should not be assumed that increases in spending equate to, or even approximate, increases in effectiveness with respect to security-related problems. Specific outlays have been challenged in terms of how well they contribute to fighting terrorism, and whether their existence reduces the ability to engage in other, more effective, activities. The defense budget includes several large weapons systems, including, for example, the F-22 high-performance fighter aircraft, which was originally designed to counter expected next-generation Soviet systems. With the breakup of the Soviet Union, this threat has not materialized and is not expected to, yet the system remains in place and accounts for $\$ 72$ billion in future spending commitments, not counting likely future cost growth. Indeed, the overall Bush defense program will require extensive further increases in federal spending, if current plans are carried out. With tax cuts and spending growth in other areas, this is a classic recipe for a budgetary train wreck. ${ }^{11}$

${ }^{8}$ Richard Kogan and David Kamin, "President's Budget Contains Larger Cuts in Domestic Discretionary Programs than has Been Reported," Center on Budget and Policy Priorities, February 5, 2004, at www.cbpp.org/2-5-04bud.htm.

${ }^{9}$ Nicholas Johnson and Rose Ribeiro, "Severe State Fiscal Crisis May be Worsening," Center on Budget and Policy Priorities," May 9, 2003, at www.cbpp.org/5-9-03sfp2.htm. Cuts in funding for first responders have also been noted at the federal level; see Robert Block, "Police, Firefighters to Get Less," Wall Street Journal, February 3, 2004.

${ }^{10}$ See, e.g., Martin Muhleisen and Christopher M. Towe, eds., U.S. Fiscal Policies and Priorities for Long-Run Sustainability, Occasional Paper No. 227 (Washington, D. C.: International Monetary Fund, 2004).

${ }^{11}$ See Steven Kosiak, "Cost Growth in Defense Plans," Center for Strategic and Budgetary Assessments, August 26, 2003, at www.csbaonline.org; and David Gold, "The Coming Bush Defense Budget Train Wreck in Historical Perspective," Paper presented at the New School University Study Group on the Economics of Security in a Post 9/11 World, November 14, 2003, at worldpolicy.org/projects/110503SG.html. 
At the same time, a number of programs that are more directly involved with counter-terrorist activities have had trouble securing adequate funding. One is the Cooperative Threat Reduction Program, popularly called Nunn-Lugar, designed to fund the securing of fissile materials within the former Soviet Union. The Bush Administration originally sought to eliminate this program, and has funded it since at levels below the minimum threshold of effectiveness. In another example, the U.S. has still not created a single database of suspected terrorists, relying instead on lists from eight different agencies. This situation has persisted for more than a decade after the first World Trade Center bombing, when the problem first received national attention, and for more than two years after 9/11, following which President Bush, on several occasions, committed the government to creating a single, usable list. On December 1, 2003, an inter-agency body, the Terrorist Screening Center (TSC), was opened within the FBI to consolidate data, weed out obsolete information, and develop new technology to better identify suspected terrorists. However, the TSC suffers "from the lack of a dedicated budget" and "ongoing failures to obtain the cooperation of several agencies to share their information ...." In the view of one critic, the TSC "is a hollow box." 12

Perhaps the most prominent example is the war in Iraq, which was justified by Iraq's ongoing programs of weapons of mass destruction (WMD), in violation of United Nations sanctions; its links with major terrorist groups; and the possibility that it would, in the future, supply WMD to these terrorist groups and thereby threaten the United States and its people and vital interests. ${ }^{13}$ The overriding theory behind these justifications was that international terrorist groups can only exist with state sponsorship, and if that sponsorship is removed or seriously threatened, terrorist groups will be far less effective. These justifications were widely debated prior to the war. In the wake of the war, however, in the absence of any Iraqi WMD and lacking any serious evidence regarding the Hussein regime's links with international terrorist organizations, it has become harder to maintain the argument that the massive amounts being spent in Iraq are effective in fighting terrorism.

More recently, evidence has surfaced regarding Pakistan's nuclear weapons program, indicating that Pakistani scientists, perhaps with assistance from military and intelligence personnel within the government, transferred nuclear weapons technology to Iran, Libya, and North Korea, countries that the

\footnotetext{
${ }^{12}$ Robert Block, Gary Fields and Jo Wrighton, “U.S. ‘Terror' List Still Lacking,” Wall Street Journal, January 2, 2004.

${ }^{13}$ Deputy Secretary of Defense Paul Wolfowitz presented this set of justifications in an interview with Vanity Fair magazine, published May 9, 2003. A transcript of the telephone interview is available on the Defense Department web site, www.defenselink.mil/transcripts/2003/tr20030509-depsecdef0223.html. Interestingly, Wolfowitz raised and explicitly rejected what has become the most commonly voiced ex poste justification, the Hussein regime's "criminal treatment of the Iraqi people..., a reason to help the Iraqi people but ... not a reason to put American kids' lives at risk, certainly not on the scale we did...."
} 
United States has linked to terrorist groups in the past. ${ }^{14}$ At the same time, AlQaeda and elements of the Taliban remain active in Western Pakistan and in Afghanistan, making reconstruction and political transformation in Afghanistan considerably more difficult. ${ }^{15}$ Pakistan is considered an ally in the war against terrorism, and has received U.S. financial and political support. The need to maintain occupation and combat forces in both Afghanistan and Iraq is tying up about half of all U.S. ground forces, counting those needed for rotation and support. Another added effect is that recruitment of new forces has become more difficult. These conditions are bound to reduce the overall U.S. ability to utilize security forces in counter-terrorism activities. ${ }^{16}$

\section{Economic Sources of Terrorism}

Following September 11, the response of many people was to attribute the wave of violent terrorism to deficiencies in the development process, particularly the persistence of poverty in many developing countries - especially the contrast between the wealth of the few and the poverty of the many - and to the absence of effective education, widely seen as both a source of economic development and an overall "civilizing" element. Alan Krueger and Jitka Maleckova examined available evidence on the links between poverty and education, on the one hand, and the incidence of terrorist activities on the other, and found "little connection between poverty or education and participation in terrorism."17 They explored data on the education and income levels of those engaged in terrorist organizations, opinion polls on attitudes toward terrorism, and data on income and poverty levels in populations where terrorism has grown. Terrorism seems unrelated to economic deprivation. Indeed, Krueger and Maleckova cite evidence that participants in terrorist organizations and terrorist activities seem to be of higher education and income status than the bulk of the populations from which they are drawn. Based on the evidence they evaluate, Krueger and Maleckova conclude that the absence of civil liberties, rather than economic deprivation, and the quality and content of education, rather than its level,

${ }^{14}$ David E. Sanger and William J. Broad, "From Rogue Nuclear Programs, Web of Trails Leads to Pakistan," New York Times, January 4, 2004; Mark Landler and David E. Sanger, "Pakistan Chief Says it Appears Scientist Sold Nuclear Data," New York Times, January 24, 2004.

${ }^{15}$ For an example, see, Andrew Higgins, "U.S. Ambitions Run Into Reality On an Afghan Road," Wall Street Journal, February 6, 2004.

${ }^{16}$ A study from the United States Army War College makes exactly this point; see Jeffrey Record, "Bounding the Global War on Terrorism," Strategic Studies Institute, U. S. Army War College, Carlisle, PA, December 2003, at www.carlisle.army.mil/ssi/pubs/2003/bounding/bounding.htm

${ }^{17}$ Alan B. Krueger and Jitka Maleckova, "Education, Poverty and Terrorism: Is There a Causal Connection?” Journal of Economic Perspectives 17:4 (Fall 2003): 141. See also, Alan B. Krueger and Jitka Maleckova, “Does Poverty Cause Terrorism?” The New Republic, June 24, 2002; and Claude Berrebi, "Evidence About the Link Between Education, Poverty and Terrorism Among Palestinians," Princeton University Industrial Relations Section Working Paper \#477, September 2003, at www.princeton.edu/ c cberebi/edu-pov-terror.pdf 
appear more important as determinants of terrorist activity.

The data cited by Krueger and Maleckova, and the work of Krueger's student, Claude Berrebi, are wide ranging, but the interpretations may be too narrow. For example, both Eli Berman and Jessica Stern, the latter based on first-person interviews, point out that the actual terrorists are drawn from a large pool of volunteers who tend to be from the poorest segments of their societies, a point Krueger and Maleckova recognize but apparently feel is superceded by additional evidence. Stern quotes a disillusioned jihadist:

'Most of the people who join these groups are from the poorest classes. Eighty-five percent come from below the poverty line, twelve percent are from the middle classes, and around three percent from the rich.' 18

Those selected for missions are likely to be those thought to be the most committed, but also the most capable of handling the complexities and difficulties that might arise, and therefore they have higher education and technical skills than most members. As Berman points out, "One would hardly expect Al Qaeda to send some of its thousands of semi-literate mercenaries in Afghanistan to flight school in Florida if disaffected students in Europe were available."19

In addition, research on terrorist groups and on other groups that use violence suggests a number of avenues where economic considerations may be important. Economics is not just about whether specific economic variables are sources of studied outcomes. It is primarily about how the inter-relations between incentives and constraints shape behavior and objectives. In this regard, two bodies of research may be useful.

One is on criminal gangs and rebel groups in civil wars, where similar patterns have been observed. In one example, Levitt and Venkatesh describe the organization of a drug dealing gang in an inner-city neighborhood. ${ }^{20}$ Most such gangs originated as social organizations to give mostly younger people a sense of community and identity in an environment that they experienced as increasingly impersonal and hostile. With the introduction of crack cocaine in the 1980s, a product characterized by low cost, high markup, and ease of use, many

\footnotetext{
18 Stern, Terror in the Name of God, 214.

${ }^{19}$ Eli Berman, "Hamas, Taliban and the Jewish Underground: An Economist's View of Radical Religious Militias," National Bureau of Economic Research Working Paper No. w10004, September 2003, 3, at www.nber.org/papers/w10004

${ }^{20}$ Steven D. Levitt and Sudhir Alladi Venkatesh, "An Economic Analysis of a Drug-Selling Gang's Finances," Quarterly Journal of Economics 115:3 (August 2000): 755-89. The name and location of the gang are kept anonymous, but in a companion article about a similar gang, the name is identified and the location given as Chicago. See Sudhir Alladi Venkatesh and Steven D. Levitt, “'Are We a Family or a Business?' History and Disjuncture in the Urban American Street Gang," Theory and Society 29:4 (August 2000): 427-62. www.sociology.columbia.edu/people/professors/sv185/miscellaneous/family_or business.html
} 
gangs turned to drug dealing. The gang studied by Levitt and Venkatesh kept a detailed set of books as a management tool. Studying this material revealed a gang organized in a way similar to a franchise in a national or international retail organization. Whatever their motives for originally joining the gang, the members' prospects for economic advancement became dominant. Unlike (most) franchises in the legal world, the gang engaged in substantial expenditures related to violence, such as hiring contractors ("muscle"), purchasing weapons, and paying for funerals. Competition for markets, in this world, often involved violence.

Research on organizations engaged in civil wars has led to similar findings. A gray area in the analysis of terrorism is the fact that terrorism frequently overlaps with civil war. Some groups that practice terrorism, such as the IRA in Ireland and England, Hamas in Israel, and others, see themselves as being in revolt against an occupying power. Similarly, in civil wars, while the primary targets are opposing armies, terror against civilians has been utilized as a tactic. Groups join or instigate rebellions for a variety of reasons, but a growing body of research suggests that they increasingly continue their activities for economic gain. Paul Collier and his colleagues at the World Bank conclude that rebellions, whatever their origins, tend to persist when accompanied by low levels of economic development, a natural resource that is an easy target for predation, and a government that is not capable of protecting that resource, perhaps due to unfavorable geography. ${ }^{21}$ Thus, state failure and the prospects for economic gain, rather than political or ideological grievance, are key elements in the persistence of rebellions. David Keen describes civil war as the continuation of economics by other means, emphasizing a country's failure to create and sustain the institutional framework for normal economic activity as a frequent cause of rebellion. ${ }^{22}$ In this analysis, poor development plays a key role, in that it creates masses of people with few alternatives - essentially with zero opportunity costs - who become natural recruits for a rebel group. An example of these transitions is the career of Angola's Jonas Savimbi, who started out as the charismatic leader of a rebellion seeking to overthrow Portuguese colonial rule, moved to the right while gaining support from the U.S. against a Soviet-backed government, and then, after the end of the Cold War, led military attacks on the government in order to steal diamonds. At the time of his death in 2002, Savimbi was an extremely wealthy man.

A second body of research is on terrorist groups themselves. Many of these groups appear to be moving in directions similar to those observed in gangs and rebel movements. Stern describes, for example, individuals who have

\footnotetext{
${ }^{21}$ Paul Collier, et al., Breaking the Conflict Trap: Civil War and Development Policy (Washington, D.C.: World Bank, 2003); Paul Collier and Anke Hoeffler, "On Economic Causes of Civil War," Oxford Economic Papers 50 (1998): 563-73.

22 David Keen, The Economic Functions of Violence in Civil Wars, Adelphi Paper No. 320 (Oxford: Oxford University Press for the International Institute of Strategic Studies, 1998).
} 
become disaffected with their organization. ${ }^{23}$ One such individual is making a good salary - better than he could get in the civilian sector.... But he sees his bosses getting rich off jihad and has come to feel disgusted. They have dirty offices and serve you bad food just to prove they have no money. But they live in mansions.... Jihadi organizations receive a lot of donations, and a lot of the money ends up going to the leaders.

Stern quotes a second disillusioned jihadi member:

'At first I thought [the bosses] are serving a religious cause, but now I feel they are running a business. They are ... suppliers of human beings. They use poor and illiterate boys for their own private cause and call it jihad.... The ... real methods for raising funds is smuggling of goods through Afghanistan, Iran and India. This includes drug trafficking, in some cases to India.... The mujahideen bring with them many smuggled items such as cosmetics and ... electronic goods from Afghanistan and Pakistan to raise funds.'

And a third:

'Initially I was of the view that they were doing jihad, but now I believe that it is a business and people are earning wealth through it.... I thought [the leaders] were true Muslims, but now I believe that they are fraud, they are selling Islam as a product..... First I was there for jihad, now I am there for my financial reasons.'

As Stern points out, as with any profession, there are non-pecuniary benefits: Not only money is important: emotional satisfaction and status are critical. Operatives describe the emotional satisfaction of their work, and the status they earn in their community. 'One becomes important due to his work. Successful operations make a militant famous and glamorous among his fellow men...'

Both Berman and Stern have studied terrorist groups that are successful because they provide services to the populations within which they reside. Hamas, for example, has become a successful social service agency, and the Taliban first achieved prominence by offering effective security on trade routes between Afghanistan and Pakistan after the withdrawal of the Soviet Union, while Pakistan-based jihadi groups have organized entire communities. These terrorist groups become providers of local public goods, in effect filling in gaps left by the failure of governments and international organizations. Private groups that supply public goods, known as "club" goods, create mechanisms that allow them to control access to the goods and services being supplied. For Berman and others who have worked on these issues, the need to control access explains

${ }^{23}$ Stern, Terror in the Name of God, 213-17. 
the elaborate selection processes and the resort to violence on the part of terrorist groups, even when this behavior does not appear to bring them close to their stated objectives. They are, instead, devices to bind members to the group and make it difficult for them to leave, thereby providing a solution to the "free rider" problem inherent in all public goods production. When governments supply public goods, their activities are financed via taxation. Private suppliers of public goods raise funds externally via charities, appeals to a diaspora, or from various governments and international organizations.

Terrorist groups, criminal organizations, and participants in civil wars, whatever their original motives, become increasingly involved either with the business of making money or with the provision of social and economic services that governments are incapable or unwilling to provide. Researchers have identified a phenomenon of "agenda shifting." Organizations that may originally have had a political objective shift their activities towards wealth accumulation in the illegal economy - obtaining and selling drugs, diamonds, minerals, timber, guns, etc. The original rationale for moving into illegal activities is usually to raise funds for the continuation of political work. Both the Taliban and Al-Qaeda, for example, despite strong religious prohibitions against the drug trade, have used the growing and trading of opium as an important revenue source. ${ }^{24}$ Many researchers argue, however, that wealth accumulation becomes the dominant goal and political activity becomes a justification, not an objective. In addition, the political justification permits groups to engage in various forms of fund-raising, including from private charities and individuals in Europe and North America. External fund raising is important, since it allows the organizations to be increasingly devoted to political and military-type activities that are effectively motivated by the objective of maintaining the groups' integrity.

\section{Economic Policies to Combat Terrorism}

Terrorism is a complex phenomenon, and fighting it requires a multiplicity of tools, including security (military and policing), politics and diplomacy, economic and social policy, etc. Yet frequently, it is the security aspect that is emphasized. When an act of terrorism occurs, the response of governments is usually to retaliate in kind, and then formulate a series of additional measures designed to punish and weaken the perpetrators. This punishment/deterrence formula has a number of advantages. It provides a sense of immediate gratification, as the shock of experiencing an attack is quickly followed by the satisfaction of inflicting punishment on those responsible. For a government, this conveys a sense of legitimacy, that "something" has been done to satisfy the citizenry's desire for a visible response.

${ }^{24}$ Douglas Farah, “Al Qaeda Gold Moved to Sudan," Washington Post, September 3, 2002; Owais Tohid, "Bumper Year for Afghan Poppies," Christian Science Monitor, July 24, 2003; Bronwyn Curran, "Afghan Opium Trade Widens, Taliban and al-Qaeda Linked to Drugs Money," AgenceFrance-Presse, October 30, 2003. 
Responding to a terrorist event after it occurs may also be justified on comparative cost grounds. The main alternative to the punishment/deterrence model is a preventive model, where the root causes of terrorism are addressed in order to limit, or possibly even prevent, its growth. But since the number of actual terrorist incidents is far less than the number of potential terrorist incidents, decisions about resource deployments are easier when security agencies concentrate on responses. A similar problem occurs in local policing, where police agencies do not have the resources to deploy personnel at all possible targets of crime. Instead, they seek to patrol or monitor those locations deemed most likely to experience crime, or locations where the consequences of crime might be greatest in terms of the value of property or the possible loss of life, and devote substantial resources to detection and apprehension once crimes are committed.

There is, however, another side to the issue of comparing strategies, that of the relative benefits. Responding in kind to terrorist incidents may be psychologically and politically satisfying, but it is not clear that it is effective. It may, of course, be hard to evaluate success, since it is difficult to measure the number and size of terrorist operations that are not undertaken because of effective deterrence. In one example where retaliation may have had minimal impacts, after the bombing of a Berlin discothèque in 1986, the U.S. launched an attack against targets in Libya. In the following months, the incidence of terrorist attacks against American and British targets first increased, then tapered off, and then resumed their previous pattern. It appears that the U.S. retaliation induced terrorists to move planned operations forward in time, as a response to the U.S. action, but did not reduce the total number of incidents. ${ }^{25}$

There are a number of economic principles that appear useful in formulating strategies to combat terrorism. One is the principle of substitution. ${ }^{26}$ As illustrated in the Libya example mentioned above, terrorist groups behave as if they are cost-constrained, and therefore choose tactics they believe to be costeffective. If the relative costs of one avenue of action are raised, terrorists have shown themselves willing and able to shift to other tactics, or to move to different locations or time periods. In the present context, the U.S. has expended substantial resources to improve airline safety since September 2001, but has been much slower, and has devoted far less resources, to improving shipping security. As of early 2003, only four per cent of containers arriving at U.S. ports were subject to inspection, and there have been identifiable lags in the development and application of inspection technology. This is despite the fact that terrorism

\footnotetext{
${ }^{25}$ Walter Enders and Todd Sandler, "The Effectiveness of Anti-Terrorism Policies: Vector Autoregression-Intervention Analysis," American Political Science Review 87:4 (1993): 829-44. A similar pattern has been observed regarding Israeli retaliation against Palestinian attacks.

${ }^{26}$ See, e.g., Sandler and Enders, "Effectiveness of Anti-Terrorism Policies," and Jurgen Brauer, "On the Economics of Terrorism," March 12, 2002, at www.aug.edu/\%7Esbajmb/.
} 
experts have identified incoming shipping as the most likely means to be used by a terrorist group for importing WMD into the U.S., a possibility that would appear even more likely with the intensification of airport security. Cindy Williams, a former Congressional Budget Office defense budget specialist, has estimated that shifting \$5 billion from the Defense Department would allow the U.S. to increase inspection of containers by a factor of ten. ${ }^{27}$

These examples of the under-funding of counter-terrorism activities suggest the importance of another economic principle, that of opportunity cost. While governments often treat their resources as infinitely expandable, the reality is that large increases in one set of programs often are accompanied by greater difficulties in funding other programs. In the area of security, the massive increases in offensive military operations and programs since 9/11 have not been accompanied by an equivalent growth of programs that are primarily defensive in orientation, as well as those that could be classified as preventive. In some cases, administration budget officials have acted to restrict the growth of defensive programs, on the grounds that budgetary resources are too tight. Too often, programs are approved without comparative evaluations, and those with the strongest political, institutional, and regional support have the upper hand. The result, in too many areas, is a weakening, not a strengthening, of the U.S. security posture.

A third important principle is to recognize the role of incentives. One prominent example of the failure to recognize incentives is in one of the main programs the U.S. adopted after the Cold War to deal with the potential problem of securing fissile materials. The former Soviet Union (FSU) had committed to dismantling a large number of its nuclear warheads, and the U.S. agreed to pay the FSU for the highly enriched uranium (HEU) that would be removed from the warheads, have the FSU "down blend" the HEU with newly mined uranium to create low enriched uranium (LEU), which would be suitable as nuclear fuel but was no longer suitable for the construction of nuclear weapons. The U.S. would then use the LEU for nuclear fuel.

The first Bush Administration negotiated this arrangement and established the quasi-governmental United States Enrichment Corporation as the U.S. government agent for the purchase and re-sale of the Russian LEU. But the Bush Administration committed itself to privatize the United States Enrichment Corporation, a commitment the Clinton Administration honored, despite the explicit objection of its chief economist, Joseph Stiglitz. The issue was that the privatized firm, re-named USEC, would have the wrong incentives. As a private firm, its primary responsibility was to its shareholders, not the U.S. government's national security objectives. And to meet its private objective of prof-

\footnotetext{
${ }^{27}$ Cindy Williams, "Paying for the War on Terrorism: U.S. Security Choices since 9/11," Paper prepared for ECAAR panel, Allied Social Sciences Association annual meetings, January 5, 2004, at www.ecaar.org/Articles/AEA2004.htm. Al-Qaeda, of course, has utilized maritime tactics in the past, as in the bombing of the U.S.S. Cole in Yemen.
} 
itability, USEC would seek out sources of uranium at low prices; there was no guarantee that it would purchase all the LEU that the Russians had available to sell from the down-blending of HEU. Alternatively, a national security objective would have been to remove this material from weak Russian storage facilities, prevent its leakage onto the black market, and give Russia the incentive to dismantle as many nuclear warheads as possible. Meeting this objective would have required the U.S. to purchase all the HEU the Russians could provide, regardless of price.

The USEC issue is an example where the incentives appropriate for national security may be incompatible with the incentives appropriate for private efficiency. ${ }^{28}$ It also highlights another important economic principle, that of the provision of public goods. Pure public goods cannot be supplied by private markets, even if there is a demand for the good, since there is no way to charge a price for its use, and no way to ration the good among users. National defense is the classic example of a public good, which is financed by public revenues i.e., taxation and borrowing - since it is not possible to exclude free riders from using the services rendered. Using budgetary resources to purchase all available FSU supplies of HEU would appear to fit the definition of a public good. In addition, as Berman and others have argued, one source of the strength of terrorist groups is their ability to supply local public goods and enforce membership in the club that utilizes the good supplied. An alternative is for governments to produce and equitably distribute these public goods to all members of the community, without imposing onerous restrictions on who can participate. The public goods in question cover a range of issues - economic, social, political, and security - and would go a long way toward filling in the gaps created by the failures of previous governments.

As discussed above, there is some controversy as to the role of poverty and development failures in breeding terrorism. Not all poverty-stricken societies breed terrorists, and not all terrorists are poor or suffer from a lack of public goods, a dearth of individual opportunities, or the absence of civil liberties. Indeed, terrorism may more resemble crime, which is never fully eradicated even in wealthy societies, than it does war, in that a successful fight will reduce but not eliminate terrorism, while a successful war would likely eliminate an enemy. The examples given above are meant to suggest that applying economic principles may broaden the range of tools available for use in this particular fight.

\section{Conclusion}

Recognizing that terrorists, acting both as individuals and as groups, are eco-

\footnotetext{
${ }^{28}$ See, e.g., Joseph Stiglitz, Globalization and its Discontents (New York: W. W. Norton \& Company, 2002) 176-78; Matthew Weinstock, "Meltdown," Government Executive (February 2001): 31-37, at www.govexec.com/features/0201/0201s2.htm; Richard Falkenrath, "Uranium Blues: Economic Interest vs. National Security," Milken Institute Review (Fourth Quarter 2000): 34-48, at www.milkeninstitute.org/publications/review/2000_12/34-48mr8.pdf.
} 
nomic beings would add to our understanding of the phenomenon of terrorism and to the formulation of policies to combat and minimize terrorism. Treating terrorism as the product of economic deprivation is an incomplete explanation, just as treating crime as the result of poverty is unsatisfactory. Yet societies where individual opportunity and aggregate growth prospects are restricted are more likely to shift individual choices towards those that are at best antithetical to widespread growth and development, and at worst violence-prone. On the basis of this analysis, here are the essentials for policy-makers:

- First, ensuring security is essential, but with limited resources, more attention needs to be paid to the effectiveness of specific policies in terms of the objective of reducing terrorism.

- Second, the opportunity costs of security policies need to be thoroughly evaluated. This is difficult, since security policies are formulated in a highly charged political context and are supported by powerful interests. But the costs of bad choices can be very large.

- Third, policies need to address both resource gaps and governance gaps. Thus, aid and security need to be supplied together, a lesson that is being learned, hopefully, in Afghanistan.

- Finally, policies should evaluate and address incentive structures; we should not assume that all terrorists are irrational, or simply hateful. Improving the range of alternatives realistically available, including effective participation and concrete evidence that social, political, economic, and security conditions are improving - and will continue to improve - may not remove all terrorist impulses, but it is highly likely to reduce their appeal. 


\section{Bibliography}

Special Report: Suicide Terrorism: Martyrdom and Murder. The Economist (2004).

Stern, Jessica. Terror In the Name of God: Why Religious Militants Kill. New York: HarperCollins, 2003.

Sandler, Todd, and Walter Enders. "An Economic Perspective on Transnational Terrorism." European Journal of Political Economy (2000).

Enders, Walter, and Todd Sandler. "Terrorism and Foreign Direct Investment in Spain and Greece." Kyklos 49, no. 3 (1996): 331-352.

Kogan, Richard, and David Kamin. President's Budget Contains Larger Cuts in Domestic Discretionary Programs than has Been Reported. Center on Budget and Policy Priorities, 2004.

Kosiak, Steven. Cost Growth in Defense Plans. Center for Strategic and Budgetary Assessments, 2003.

Block, Robert, Gary Fields, and Jo Wrighton. "U.S. 'Terror' List Still Lacking." Wall Street (2004).

Sanger, David E., and William J. Broad. "From Rogue Nuclear Programs, Web of Trails Leads to Pakistan." New York Times (2004).

Landler, Mark, and David E. Sanger. "Pakistan Chief Says it Appears Scientist Sold Nuclear Data." New York Times (2004).

Higgins, Andrew. "U.S. Ambitions Run Into Reality On an Afghan Road." Wall Street Journal (2004).

Record, Jeffrey. Bounding the Global War on Terrorism. Strategic Studies Institute, U. S. Army War College, Carlisle, PA, 2003.

Krueger, Alan B., and Jitka Maleckova. "Education, Poverty and Terrorism: Is There a Causal Connection?" Journal of Economic Perspectives 17, no. 4 (2003): 141 .

Krueger, Alan B., and Jitka Maleckova. "Does Poverty Cause Terrorism?" The New Republic (2002).

Berman, Eli. Hamas, Taliban and the Jewish Underground: An Economist's View of Radical Religious Militias. National Bureau of Economic Research Working Paper, 2003.

Levitt, Steven D., and Sudhir Alladi Venkatesh. "An Economic Analysis of a Drug-Selling Gang's Finances." Quarterly Journal of Economics 115, no. 3 (2000): 755-789. 
Levitt, Steven D.. "Are We a Family or a Business?' History and Disjuncture in the Urban American Street Gang." Theory and Society 29, no. 4 (2000): $427-62$.

Williams, Cindy. Paying for the War on Terrorism: U.S. Security Choices since 9/11 In ECAAR panel, Allied Social Sciences Association annual meetings., 2004.

Stiglitz, Joseph. Globalization and its Discontents. New York: W. W. Norton \& Company, 2002. 